\title{
Pelatihan Membuat Keripik Singkong dan Talas di Desa Brongkal, Kecamatan Pagelaran Kabupaten Malang
}

\author{
Siane Herawati ${ }^{1}$, Giovanni Irawan'2, Mujiono ${ }^{3}$ \\ ${ }_{1,3}^{3}$ Pendidikan Bahasa Inggris, ${ }^{2}$ Sastra Inggris, ${ }^{1,2,3}$ Fakultas Bahasa dan Sastra, \\ 1,2,3 Universitas Kanjuruhan Malang \\ e-mail: ${ }^{1}$ siane.herawati@yahoo.com, ${ }^{2}$ giovanni.irawan@gmail.com, ${ }^{3}$ moejie_nova73@yahoo.com
}

\begin{abstract}
Abstrak
Artikel ini memaparkan hasil kegiatan pengabdian masyarakat yang dilakukan di desa Brongkal, yang bertujuan untuk mengatasi masalah pengerajin keripik singkong dan talas. Kegiatan yang dilaksanakan yaitu: a) memodifikasi perajangan yang manual menjadi perajangan listrik atau elektrik, b) membuat keripik singkong dan talas higienis dan beranekan rasa dengan menggunakan komposisi alami, c) membuat pengemasan lebih baik dan menarik dengan memberikan label, merk, komposisi bahan, ijin perdagangan, dan d) mengembangkan pemasarana dengan cara online. Metode yang digunakan adalah: a) pembuatan/pengadaan alat, dan b) pelatihan dan pendampingan. Beberapa hal telah mengalami peningkatan diantaranya, 1) Pada proses pengolahan keripik di desa Brongkal tidak menggunakan bahan tambahan bahan kimia seperti penyedap rasa, ataupun pengawet makanan. Selain itu proses pengolahan makanan yang tepat dan sesuai standard. Proses pengepakan dan pelabelan telah dilaksanakan oleh masyarakat di desa Brongkal untuk membantu peningkatan produksi dan perekonomian warga masyarakat. 2) Pada jenis variasi keripik singkong dan talas teah sesuai dengan selera masyarakat. Selain itu produk ini mampu menjadi makanan yang diharapkan menjadi daya tarik kuliner di Jawa timur. 3) Produk keripik singkong dan talas desa Brongkal dengan proses pengolahan, pengepakan dan pelabelan merupakan hasil penelitian, inovasi kreatifitas Unikama. 4) Mendukung program pemerintah dalam upaya diversivikasi pangan dengan menggunakan pemanfaatan bahan makanan local yang berkualitas.
\end{abstract}

Kata Kunci: pelatihan; pendampingan; pengemasan; pengolahan keripik

\begin{abstract}
This article describes the results of community service activities conducted in Brongkal Village, it aims at overcoming the problems of people who produce cassava and taro chips. The activities carried out are: a) modifying the manual cutting to be electricity or electrical, by using the cassava and taro chopper machine, b) making cassava and taro chips hygienist and the flavour is varied by using natural composition, c) creating better and more interesting packaging by giving label, brand, composition, trading license, and d) developing the marketing through online marketing. The methods used are: a) the manufacture/procurement of equipment, and b) training and mentoring. The result of this activity are a) the processing of chips in Brongkal village does not use chemical additives anymore such as flavoring, or food preservatives. Besides, the food processing has followed the standard. The process of packing and labeling have been carried out by the community in the Brongkal village so that it increases the economy of the community. b) The type of variety of cassava and taro chips has differences to other products then the taste fits to the people. In addition, this product can be expected to be a culinary attraction in East Java. 3) By using processing, packing and labeling, the cassava and taro chips become the outcome of research and Unikama's creative innovation. 4) It can support the government programs to diversify food by using qualified local food ingredients.
\end{abstract}

Keywords: training; mentoring; packaging; processing of chips 


\section{PENDAHULUAN}

Desa Brongkal sebagai salah satu desa di wilayah Kabupaten Malang yang merupakan desa yang berbatasan langsung dengan calon ibu kota Kabupaten Malang di Kepanjen, mempunyai peranan yang sangat besar dalam mendukung percepatan pembangunan daerah kabupaten Malang khususnya di wilayah lingkar Kota Kepanjen. Wilayah Brongkal mempunyai sumber alam yang subur baik berupa mata air maupun sumber daya alam lainnya, sehingga dalam perkembangan ke depan daerah ini membutuhkan perencanaan dan penataan yang sinergis dan berkesinambungan, dengan harapan agar nantinya wilayah ini dapat mandiri dan lebih dikenal oleh masyarakat luas di luar kabupaten Malang, utamanya dalam mendukung upaya pemerintah dalam pemanfaatan pengolahan sumber daya alam. Desa Brongkal ini juga merupakan daerah dataran dengan potensi lahan adalah pertanian yang meliputi tanaman padi, singkong dan tebu dengan curah hujan rata - rata pertahun antara $1,297 \mathrm{~mm}$ s.d 1,925 $\mathrm{mm}$ dengan suhu rata - rata 20 - $26 \mathrm{C}$, akses perekonomian akan cepat berkembang apabila didukung dengan sarana promosi terhadap produk yang ada. Sementara penduduk desa Brongkal ini bermata pencaharian sebagai petani, buruh, buruh bangunan dan sebagaian bekerja sebagai TKI atau TKW.

Berlatar belakang dari pekerjaan yang diminati oleh penduduk desa Brongkal dan tersedianya lahan yang digunakan untuk pertanian yang sebagian telah ditanami singkong dan talas sebagai mata pencaharian mereka. Singkong dan talas mereka jual mentah di pasar, sebagian lagi di jadikan makanan tradisional seperti tiwul, tapi seiring dengan perkembangan jaman yang ada serta beragam makanan yang lebih menarik bagi masyarakat sekitar maka singkong mentah dan tiwul semakin kurang peminatnya. Sehingga pendapatan merekapun semakin menurun. Sementara dalam proses pembuatan tiwul tersebut juga cukup lama dan tidak tahan lama. Pendapatan yang mereka harapkan tidak sesuai dengan hasil yang mereka terima bahkan kerap kali justru rugi.
Sehingga warga tersebut mulai berpikir untuk bagaimana cara mengolah singkong menjadi makanan yang bisa laku. Mereka berinisiatif untuk menjadikan singkong dan talas sebagai keripik dan dipasarkan di toko-toko dan pasar daerah Brongkal dengan harapan singkong dan talas yang telah diolah menjadi lebih menarik dan lebih tahan lama.

Sayangnya mereka hanya mengolah singkong dan talas dengan peralatan yang sangat sederhana yaitu dalam proses pemotongan yang hanya manual, pengolahan dengan peralatan yang sederhana, proses pengeringan mengandalkan panas matahari dan pengemasan. Masalah masalah yang di hadapi para pengolah singkong dan talas dalam pembuatan keripik ini cukup kompleks, mereka tetap saja tidak bisa memanfaatkan singkong dan talas dengan maksimal, sehingga harapan untuk mendapatkan penghasilan lebihpun tidak tercapai.

Menyimak permasalahan diatas dalam proses pengolahan sampai pengemasan mereka selalu menggunakan alat seadanya hanya menggunakan pisau biasa untuk memasak, sehingga memerlukan waktu yang sangat lama, dan butuh tenaga lebih banyak untuk bisa memotong singkong tersebut, dalam pengolahanpun mereka menggunakan peralatan seadanya bahkan sering kali masih dicampur dengan peralatan yang lain sehingga kebersihan yang kurang, dan tidak higienis. Sementara dalam proses penjemurannyapun mereka juga masih memanfaatkan sinar matahari sehingga pengeringan akan sangat lama sementara daerah iklim saat ini tidak bisa di prediksi, dan sering turun hujan sehingga singkong dan talas tidak bisa kering dengan sempurna juga hasilnya tidak maksimal. Masalah lain yang dihadapi pengolah singkong dan talas adalah saat pengemasan, mereka menjual dengan tanpa di kemas alias curah. Mereka menggunakan plastik seadanya, tanpa merk, sehingga makanan ringan ini tidak hygienis, mudah rusak (melempem) dan tidak menarik. Terlebih lagi mereka tidak bisa menjual dengan harga yang layak sesuai dengan tenaga dan waktu yang telah mereka kerjakan. 
Hal ini tentulah sangat berbeda dengan proses pembuatan keripik singkong dan talas di Malang Raya, Penjual oleh oleh berbagai keripik yang begitu luas dan menjamur di Malang, di setiap daerah pasti ada toko pusat oleh oleh Malang. Jika kita melihat jenis dan ragam keripik saja sudah sangat banyak, ada keripik apel, keripik nangka, keripik salak, keripik kentang, keripik tempe dan lain lain. Semua terliat menarik dengan kemasan yang mewah dan bermerk. Belum lagi selalu ada label dengan komposisi bahan dan nilai gizinya. Mereka juga tidak lupa mencantumkan tanggal kadaluarsa yang sangat penting bagi para konsumen. Sehingga mereka hanya bisa menjual keripik singkongnya di daerah mereka sendiri, dengan di titipkan di toko toko kampung atau pasar pasar tradisional. Mereka tidak pernah mampu menjual ke daerah yang lebih luas atau pasar modern. Faktor lain yang tidak menunjang adalah keterbatasan informasi dan dana, pembuat keripik singkong dan talas di desa Brongkal tidak bisa menggunakan internet untuk berjualan online, mereka juga tidak memiliki dana yang cukup untuk pembiayaan produksi mereka agar layak bersaing di pangsa pasar. Dari banyaknya faktor yang tidak mendukung itulah yang membuat sulitnya keripik singkong dan talas dari desa Brongkal untuk dapat bersaing dengan makanan ringan lainnya. Sementara jika ingin menitipkan dagangannya ke area yang lebih luas, mereka harus berani merubah proses pembuatan, pengemasan dan pemasarannya. Karena jika tidak mereka akan selamanya tidak berkembang, sementara untuk saat inipun mereka tidak bisa menjual keripik singkong dan talas dengan harga yang layak atau bisa di bilang cukup murah sekali, Sehingga seringkali pengeluaran dan pemasukan yang mereka putar tidak berimbang atau bahkan uang modalpun sering kali terpakai untuk keperluan mereka di luar produksi. Praktis mereka sendiri akan kehabisan modal dan berhenti sementara sampai mereka memiliki modal lagi.

Jika masalah yang kerap kali di hadapi oleh para pembuat keripik singkong dan talas tidak bisa teratasi, dan mereka akan selamanya menggunakan proses yang sangat sederhana dengan penghasilan yang sangat minim dan ujung ujungnya justru mereka tidak dapat mempertahankan kwalitas produknya karena kehabisan modal, akan banyak berdampak pada jenuhnya mereka melanjutkan pekerjaan, sehingga malah terjadi banyak penurunan penghasilan atau bahkan pengangguran di mana mana. Akan sangat di sayangkan kalau mereka tidak dapat memenuhi kebutuhannya hidupnya sendiri sehingga angka kemiskinan semakin bertambah. Oleh karena itu perlu adanya upaya untuk membantu mengatasi masalah ini, sehingga mereka tetap bisa melanjutkan berwirausaha dan bahkan meningkatkan pendapatan dengan meningkatkan kwalitas produksi mereka, akan sangan bermanfaat lagi jika mereka bisa membesarkan usaha mereka sehingga mereka bisa menarik warga desa lain untuk ikut bekerja dalam memproduksi dan memasarkan hasil dari keripik singkong tersebut. Hal ini akan membantu mengurangi angka penggangguran di daerah sekitar desa Brongkal. Adapun tujuan dari PKM ini adalah: a) Menciptakan lapangan pekerjaan, b) Sebagai media mencari keuntungan, c) Untuk memenuhi kebutuhan konsumen, d) Mewujudkan kemampuan dalam berwirausaha untuk meningkatkan kemajuan dan kesejahteraan masyarakat, e) Memberdayakan semangat dan kemampuan kewirausahaan di kalangan masyarakat dan mahasiswa yang mampu diandalkan dalam berwirausaha.

\section{SUMBER INSPIRASI}

Berdasarkan hasil pengamatan dan wawancara pada survey yang di lakukan pada bulan Maret lalu, maka beberapa permasalahan untuk segera diatasi adalah produksi.Dalam proses pengolahan mereka masih menggunakan proses yang sangat sederhana yaitu (1) Saat pemotongan, mereka menggunakan alat pemotong seadanya, sehingga membutuhkan waktu yang sangat lama, membutuhkan banyak pekerja, membutuhkan biaya yang lebih banyak untuk membayar tenaga pekerja, hasil tidak maksimal dan kurang hygienis. (2) Saat penjemuran, mereka mengandalkan sinar matahari, 
padahal cuaca di sekitar Malang tidak lagi bisa di prediksi, cuaca panas dan dengan sesaat bisa berubah mendung dan hujan, hal ini mengakibatkan proses pengeringan pada singkong tidak bisa maksimal, sehingga saat singkong dan talas tidak betul betul kering, maka singkong dan talas akan menjadi hitam dan mudah menjamur. Maka akan merugi sebelum terjual. (3) Saat pengemasan, mereka menggunakan kantong plastik sekedarnya tanpa label merk, tanpa label komposisi dan tangan kadaluarsa, sehingga tidak menarik dan membuat konsumen merasa ragu ragu untuk membeli, disamping itu plastik tipis membuat keripik mudah melempem dan rusak. Hal ini akan membawa resiko tidak terjual maksimal dan hasil yang di harapkan tidak sesuai atau justru merugi karena faktor tidak laku.

Dengan melihat berbagai permasalahan yang di hadapi oleh warga pembuat keripik singkong dan talas di desa Brongkal ini maka berbagai permasalahan tersebut diharapkan mendapatkan permecahan yaitu Bagaimana cara meningkatkan mutu dan jumlah produksi yang lebih banyak dan cepat dengan menekan biaya serendah rendahnya. (2) Bagaimana cara penduduk desa Brongkal dalam membuat keripik singkong dan talas yang bervariasi tanpa hanya mengandalkan sinar matahari. (3) Bagaimana cara meningkatkan daya saing produksi dengan mengemas yang lebih menarik dan hygienis dan bervariasi rasa sehingga dapat meningkatkan mutu dari produksi keripik singkong.

\section{METODE KEGIATAN}

\section{Prosedur Solusi Masalah}

1) Memberikan pelatihan dalam pengoperasian alat pemotong, 2) Memberikan pelatihan cara menggunakan alat dan memberikan label pada kemasan, 3) Memberikan pelatihan mengkreasikan membuar keripik singkong dan talas dalam aneka rasa sehingga lebih di minati oleh konsumen, 4) Penyuluhan cara pengurusan ijin produksi industri rumah tangga dari dinas kesehatan kabupaten Malang, 5) Pelatihan untuk pembuatan web dan cara pemasaran online, dan 6) Pendampingan dalam pemasaran untuk mengetahui progress dari pemasaran yang mereka lakukan secara online.

\section{Kontribusi Mitra}

Partisipasi mitra dalam pelaksanaan PKM sangat menentukan keberhasilan dan keberlanjutan program. Beberapa cara untuk mendorong mitra agar memberikan partisipasi aktif dalam program pelaksanaan PKM yaitu: 1) Keterlibatan tenaga ahli sebagai motivator, 2) Peran tenaga ahli sebagai motivator khalayak sasaran program PKM sangat penting. Partisipasi khalayak sasaran yang tinggi ini tetap berlangsung meskipun tanpa kehadiran tenaga ahli. Hal ini menunjukkan bahwa peran tenaga ahli selain sebagai motivator juga memunculkan citra bahwa kegiatan ini penting sehingga apresiasi khalayak sasaran terhadap program tetap tinggi walaupun tanpa kehadiran tenaga ahli, 3) Pelatihan pengolahan variasi keripik singkong dan talas dengan melibatkan mitra pengabdian secara langsung, sehingga mereka dapat berpartisipasi secara aktif dalam pengolahan variasi keripik singkong dan talas untuk meningkatkan produksi keripik mitra PKM desa Brongkal, kecamatan Pagelaran, 4) Pengurusan ijin dagang industry makanan ringan rumahan desa Brongkal kecamatan Pagelaran yang diawali dengan mendaftarkan ijin ke Dinas Kesehatan Kabupaten Malang agar pengerajin keripik singkong dan talas mendapatkan ijin P-IRT dari Dinas Kesehatan Kabupaten Malang, 5) Kunjungan lapangan ke lokasi pembuatan keripik di desa Brongkal Kecamatan Pagelaran, menghasilkan sangat besar pengaruhnya bagi keyakinan khalayak sasaran atas program yang dilaksanakan. Dalam kegiatan ini kedua mitra akan dipertemukan agar saling bersikusi, dan 6) Pendampingan pemasaran online oleh tim ahli IT sangat bermanfaat dan disambut sangat antusias oleh khalayak sasaran. Mitra pengabdian berpartisipasi secara aktif untuk mengikuti proses pendampingan pemasaran online tersebut dan memberikan respon positif dengan selalu antusias memanfaatkan blog sebagai sarana promosi produk keripik yang diproduksi oleh mitra pengabdian. 


\section{KARYA UTAMA}

Program ini menghasilkan beberapa hal sebagai berikut: 1) Tersusunnya modul (bahan ajar) pelatihan pembuatan keripik singkong dan keripik talas aneka rasa. Bahan ajar pelatihan ini disusun sesuai kebutuhan sehingga lebih aplikatif. Dalam bahan pelatihan ini juga diuraikan langkah-langkah secara detail dalam membuat keripik singkong dan talas sehingga diharapkan kelompok usaha menggunakan alat secara mandiri dan dapat membuat keripik singkong dan talas lebih bervariasi, 2) Kelompok usaha keripik singkong dan talas memiliki alat pemotong singkong dan pengepakan serta pelabelan yang memadai sehingga produksinya lebih meningkat dan hygienis, 3) Kelompok usaha keripik singkong dan talas ini memiliki keterampilan dalam membuat keripik aneka rasa sesuai dengan minat konsumen., 4) Kelompok usaha keripik singkong dan talas memiliki keterampilan menggunakan alat pemotong dan pengepakan yang lebih modern, 5) Kelompok usaha keripik singkong dan talas memiliki alat pencetak (printer) label sehingga lebih menarik, 6) Produksi keripik singkong dan talas meningkat dan lebih variatif (aneka rasa), 7) Kemasan keripik singkong dan talas buatan desa Brongkal bagus, lebih menarik, lebih higienis dan dalam kemasan tertera label, komposisi, expired date, kode produksi, ijin perdagangan, 8) Kelopmpok usaha keripik singkong dan talas memiliki website untuk pemasaran, serta memiliki keterampilan pemasaran online. Publikasi ilmiah, 9) Aplikasi teknologi tepat guna, dan 10) Merk dagang dan hak cipta serta ijin dagang (P-IRT).

\section{Hasil yang Dicapai}

Berdasarkan rancangan evaluasi kegiatan, tahapan kegiatan pengabdian penerapan IPTEKS beserta pencpaaian indicator keberhasilan diuraikan sebagai berikut:

\section{Koordinasi}

Pada tanggal 12 dan 13 Juli 2018, tim pengabdi melaksanakan koordinasi dengan warga yang memproduksi keripik singkong dan talas di desa
Brongkal kecamatan Pagelaran, kabupaten Malang. Tim pengabdi melaksanakan sinkronisasi jadwal dan mendata alat, bahan yang dibutuhkan oleh masyarakat pembuat keripik singkong dan talas. Dari hasil koordinasi tersebut tim pengabdi mempersiapkan modul pembuatan keripik singkong dan talas, pembuatan web, cara memasarkan secara online dan offline. Tim pengabdi melaksanakan pengabdian masyarakat selama 12 kali pertemuan diantaranya pelatihan penggunaan mesin pembuatan keripik singkong dan talas, pelatihan pembuatan keripik singkong dan talas, pelatihan pembuatan web, pelatihan pemasaran online dan offline. Tim pengabdi juga membantu mengurus ijin produksi (P-IRT) dan membuatkan label dagang.

\section{Penyusunan Modul}

Tim pengabdi melakukan penyusunan modul terkait materi yang diberikan kepada mitra pengabdian sebagai acuan dan sekaligus dokumentasi pelaksanaan pelatihan dan pendampingan bagi mitra Program Kemitraan Masyarakat (PKM).

\section{Pelatihan}

a) Pelatihan penggunaan alat dilaksanakan pada tanggal 17 dan 18 Juli 2018. Pelatihan ini dihadiri oleh 15 orang peserta. Tim pengabdi beserta tenaga tim ahli mengajarkan cara memotong singkong dan

talas dengan menggunakan alat pemotong yang diberikan oleh tim pengabdi.

b) Pelatihan pembuatan keripik singkong dan talas dilaksanakan pada tanggal 17, 18, 19, 20 dan 21 Juli 2018. Tim pengabdi memberikan berbagai resep cara mengolah keripik singkong dan talas dengan aneka rasa. Tim pengabdi dibantu oleh 2 orang mahasiswa mempraktekkan berbagai macam resep cara membuat keripik singkong dan talas dengan aneka rasa.

c) Pelatihan pengepakan dan mencetak label dilaksanakan pada tanggal 27 Juli 2018. Tim pengabdi memberikan bantuan berupa alat pengemasan (sealer) dan printer kepada kelompok masyarakat yang memproduksi keripik singkong dan talas. d) Pelatihan pembuatan web, cara pemasaran online dilaksanakan 
pada tanggal 28,29 dan 30 Juli 2018. Pelatihan ini dihadiri oleh 15 orang peserta. Tim pengabdi bekerjasama dengan tim ahli memberikan pelatihan cara memasarkan secara online. Hal ini bertujuan untuk meningkatkan produksi dan pendapatan masyarakat desa Brongkal Kecamatan Pagelaran, Kabupaten Malang.

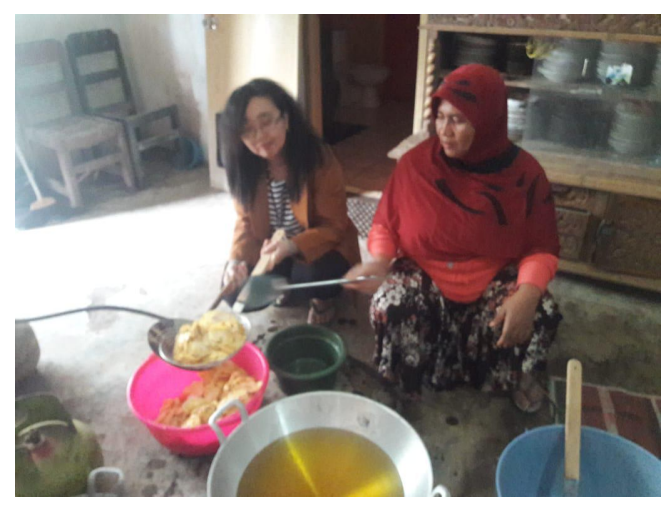

Gambar 1. Pelatihan Membuat Keripik Singkong dan Talas

\section{Pengurusan Ijin Produksi (P-IRT)}

Tim pengabdi dan mitra pengabdi bersama-sama mengurus ijin dagang untuk industri rumah tangga $(\mathrm{P}-$ IRT) untuk usaha keripik singkong dan talas di desa Brongkal, kecamatan Pagelaran pada tanggal 27 Agustus 2018. Tim pengabdi memfasilitasi dan membantu pengurusan P-IRT ke Dinas Kesehatan Kabupaten Malang.

\section{Pendampingan Pemasaran Online}

Tim pengabdi juga melakukan pendampingan bagi mitra untuk memasarkan produk secara online. Pendampingan ini dilakukan dengan membantu mitra untuk membuat blog dan memasarkan di market place sebagai ajang promosi bagi mitra pengabdian. Sampai saat ini blog pemasaran online untuk produksi keripik singkong dan talas desa Brongkal sedang dalam proses pengembangan dan pernaikan secara bertahap.

Seperti yang diungkapkan dalam analisis situasi bahwa kekurangan dan kelemahan produksi keripik singkong dan talas desa Brongkal adalah kekurangan alat penunjang produksi, sehingga mereka masih memproduksi secara manual dan pengemasan serta pelabelan masih menggunakan system sulut api.

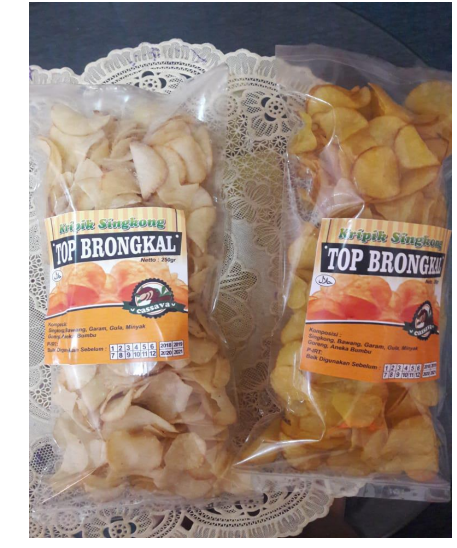

Gambar 2. Produk Keripik Singkong dan Talas

Selanjutnya dengan adanya bantuan alat pemotong singkong dan alat pengemasan produk/sealer masyarakat desa Brongkal telah menggunakan alat tersebut untuk menunjang proses produksi mereka, sehingga menghasilkan produk yang lebih berkualitas dan lebih baik dan layak jual. Hal ini dapat membantu masyarakat desa Brongkal dalam meningkatkan omset dan pendapatan mereka.

a) Adanya Ijin Usaha Dagang P-IRT. Dengan adanya ijin usaha dagang P-IRT membantu pengusaha keripik singkong dan talas desa Brongkal untuk meningkatkan produksi dan pemasaran mereka sehingga menjadi layak jual dan bias dipasarkan ke seluruh pelosok nusantara. b) Pengepakan, Pelabelan, dan Pemasaran Online. Pengepakan dan pelabelan telah dilakukan untuk meningkatkan produksi dan daya jual produksi keripik singkong dan talas desa Brongkal kecamatan Pagelaran. Dengan adanya pengepakan serta pelabelan yang memenuhi syarat ini maka akan meningkatkan daya jual produksi masyarakat desa Brongkal kecamatan Brongkal. c) Pendampingan Usaha dan Pemasaran Online. Pendampingan pengolahan keripik singkong dan talas menjadi berbagai produk yang layak jual dilaksanakan di desa Brongkal ataupun langsung bertemu di tempat usaha desa Brongkal, kecamatan Pagelaran. Bahkan juga dilakukan komunikasi melalui telepon, whatsapp sehingga permasalahan usaha produk keripik singkong dan talas dapat berjalan lancar. Pengabdian pada masyarakat ini dilakukan sampai tuntas sehingga bisa 
b) memberikan manfaat yang besar bagi masyarakat khususnya pengusaha kecil makanan ringan desa Brongkal. Blog dan market place yang dibuat dapat digunakan sebagai saran promosi produk keripik singkong dan talas dengan alamat http://kripikbrongkal.blogspot.com dan https://www.tokopedia.com/kripikbrongkal.

\section{ULASAN KARYA}

Keripik singkong dan talas di desa Brongkal ini memiliki keunggulan dibandingkan dengan keripik singkong dan talas yang diproduksi di tempat lain diantaranya: 1) Keripik singkong dan talas tidak menggunakan bahan pengawet sehingga aman dikonsumsi, 2) Bahan singkong dan talas didapat langsung dari kebun warga pengerajin sehingga harga produksi keripik singkong dan talas sangat terjangkau.

\section{KESIMPULAN}

Pelaksanaan Program Kemitraan Masyarakat (PKM) ini telah berjalan sesuai dengan rencana yang telah disusun. Masyarakat juga mengikuti seluruh program dengan antusias. Produk yang ditawarkan melalui program PKM kelompok pengerajin keripik singkong dan talas di desa Brongkal, kecamatan Pagelaran kabupaten Malang juga mengalami peningkatan mutu.

Beberapa hal telah mengalami peningkatan diantaranya, pertama pada proses pengolahan keripik di desa Brongkal ini dan tidak menggunakan bahan tambahan bahan kimia seperti penyedap rasa, ataupun pengawet makanan. Selain itu proses pengolahan makanan yang tepat dan sesuai standard. Proses pengepakan dan pelabelan telah dilaksanakan oleh masyarakat di desa Brongkal untuk membantu peningkatan produksi dan perekonomian warga masyarakat. Perbedaan kedua pada jenis variasi keripik singkong dan talas sehingga sesuai dengan selera masyarakat. Selain itu produk ini mampu menjadi makanan yang diharapkan menjadi daya Tarik kuliner di Jawa timur. Ketiga, produk keripik singkong dan talas desa Brongkal dengan proses pengolahan, pengepakan dan pelabelan merupakan hasil penelitian, inovasi kreatifitas Unikama. Keempat, mendukung program pemerintah dalam upaya diversivikasi pangan dengan menggunakan pemanfaatan bahan makanan local yang berkualitas.

Kegiatan ini masih perlu adanya pendampingan manajemen produksi maupun pemasaran produk dalam skala nasiona maupun internasional yang lebih baik. Selain itu masyarakat juga memerlukan pendampingan dalam hal pengelolahan web/blog dan lapak pemasaran keripik singkong dan talas. Program PKM ini perlu didampingi terutama dalam bantuan pengurisan ijin produksi, kualitas produk di Dinas Kesehatan, ijin usaha di Dinas Perindag, bantuan perpajakan, persiapan audit dan penerapan manajemen terbuka.

\section{DAMPAK DAN MANFAAT KEGIATAN}

Kegiatan ini berdampak positif bagi kelompok usaha makanan ringan desa Brongkal, Kecamatan Pagelaran, Kabupaten Malang, perguruan tinggi maupun bagi pemerintah daerah khususnya dinas perindustrian kabupaten Malang secara social, ekonomi maupun kesehatan lingkungan. Dampak tersebut adalah: 1) Meningkatkan pendapatan masyarakat, khususnya kelompok usaha keripik singkong dan talas desa Brongkal kecamatan Pagelaran, kabupaten Malang, dan pendapatan daerah, 2) Meningkatkan tanggungjawab profesionalisme dosen melalui pengabdian kepada masyarakat, 3) Terjalinnya kerjasama secara berkelanjutan antara Universitas Kanjuruhan Malang dengan kelompok usaha makanan ringan desa Brongkal, kecamatan Pagelaran kabupaten Malang dan Dinas Perindustrian Kabupaten Malang, 4) Meningkatkan kreativitas/inovasi kelompok usaha keripik singkong dan talas desa Bantur, kecamatan Pagelaran, kabupaten Malang dalam membuat produk kripik singkong dan talas dan pengemasannya, 5) Mengurangi pengangguran, 6) Mencegah masyarakat desa Brongkal kecamatan Pagelaran, kabupaten Malang mencari kerja di luar negeri (menjadi TKW), 7) Menerapkan teknologi tepat guna, dan 8) Pemberdayaan potensi daerah (hasil pertanian singkong dan talas). 


\section{DAFTAR PUSTAKA}

[1] Tim penyusun, Laporan Penyelenggaraan Pemerintah Desa (LPPD) Tahun 2016 Kepala Desa Brongkal, 2016. Laporan tidak Dipublikasikan.

\section{PENGHARGAAN}

Terima kasih disampaikan kepada :

1. Direktorat Riset dan Pengabdian kepada Masyarakat (DRPM) Kementerian Riset, Teknologi dan Pendidikan Tinggi yang membiayai kegiatan ini pada skema Program Kemitraan Masyarakat (PKM) tahun 2018.

2. Lembaga Penelitian dan Pengabdian Masyarakat (LPPM) Universitas Kanjuruhan Malang yang telah memfasilitasi kegiatan ini.

3. Kepala Desa Brongkal, Kecamatan Pagelaran, Kabupaten Malang yang telah memberikan kesempatan pada tim pengabdi dalam memberikan pelatihan pembuatan keripik singkong dan talas. 